\title{
PENGARUH PEMBERIAN EKSTRAK BUAH NANAS (Ananas comosus L. Merr) PERORAL TERHADAP PERBAIKAN PROFIL LIPID PADA TIKUS PUTIH (Rattus Norvegicus) JANTAN STRAIN WINSTAR DISLIPIDEMIA
}

\author{
Latifa Octadiani Putri ${ }^{1}$, Diah hermayanti ${ }^{2}$, Fathiyah $\mathrm{S}^{3}$
}

Fakultas Kedokteran Universitas Muhammadiyah Malang, Jl. Bendungan Sutami No. 188A, Kota Malang, 65145, Indonesia, (0341)551149

\begin{abstract}
ABSTRAK
Pengaruh Pemberian Ekstrak Buah Nanas (Ananas comosus L. Merr) Peroral Terhadap Perbaikan Profil Lipid Pada Tikus Putih (Rattus Norvegius) Jantan Strain Winstar Displidemia. Penelitian ini bertujuan untuk mengetahui pengaruh ekstrak nanas (Ananas Comosus L. merr) secara peroral terhadap perbaikan profil lipid pada tikus putih (Rattus norvegicus strain wistar) dislipidemia. Penelitian ini merupakan penelitian true eksperiment, dengan rancangan post test control group design. Sampel penelitian dibagi menjadi lima kelompok. Dari hasil uji One way ANOVA, didapatkan pengaruh yang bermakna (nilai sig $=0,000<\mathrm{p}(0,01)$ ) antara kelompok perlakuan. Hasil uji tukey $1 \%$ pada kelompok I, II, III, IV, dan V didapatkan notasi yang berbeda dari tiap kelompok yang artinya tiap kelompok mempunyai kadar profil lipid yang berbeda satu sama lain. Hasil uji korelasi didapatkan korelasi yang berbanding terbalik pada KT, TG, LDL, rasio dan LDL/HDL, berarti bahwa kenaikan dosis ekstrak nanas mampu menyebabkan penurunan KT, TG, LDL, dan rasio LDL/HDL dan didapatkan uji korelasi yang berbanding lurus pada HDL, yakni kenaikan dosis ekstrak nanas mampu menyebabkan peningkatan HDL pada tikus. Kesimpulan: Ekstrak nanas dapat memperbaiki profil lipid dan dosis yang paling efektif pada penelitian ini adalah $4 \mathrm{gr} / 200 \mathrm{grBB} /$ hari.
\end{abstract}

Kata Kunci: Ekstrak nanas, Myricetin, Rattus norvegicus strain wistar, perbaikan profil lipid.

\begin{abstract}
The Effects of Giving Pineapple Extract (Ananas Comosus L. Merr) Orally For Lipid Profile Improvement in White Male Rats (Rattus Norvegicus Strain Witar) Dysplidemia. The objectives of this research were to find out the pineapple extract (Ananas Comosus L.merr) personally for lipid profile improvement in white male rats (Rattus norvegicus strain wistar) dyslipedima. This research was true experimental research with post test control group design. The samples were divided into five groups. One way Anova test showed significant effect (sig value $=0,000<p(0,01)$ ) on the control and experiment groups. From Tukey test $1 \%$ result showed that there was different notation from each groups which meant each group has the differences lipid profile level. Correlation test showed inversely correlation to KT, TG, LDL, ratio of LDL/HDL means that the increase doses of extract of Aloe vera can cause a decrease in KT, TG, LDL, ratio of $\mathrm{LDL} / \mathrm{HDL}$ and correlation test showed directly correlation to HDL, which is the increase dose of Pineapple extract able to increase HDL of mice.
\end{abstract}

Key words : Pineapple extract, Polyphenol, Rattus Norvegicus Strain Wistar, Lipid Profile Improvement.

\section{PENDAHULUAN}

Bagi penderita dislipidemia, perubahan pola hidup sangat diperlukan untuk mengontrol kadar kolesterol dalam darah melalui pengaturan pola makan, olahraga teratur, tidak merokok, dan mengurangi stres. Selain itu, terapi yang dapat diberikan untuk membantu menurunkan kadar kolesterol dalam darah adalah dengan menggunakan obat sintetik maupun obat tradisional salah satunya dengan menggunakan buah nanas (Ananas comosus L. Merr) (Sabella, 2010).

\section{Nanas (Ananas comosus L. Merr)}

Ananas comosus L. Merr atau lebih sering disebut nanas diduga dapat memperbaiki profil lipid dalam darah, salah satunya adalah Myricetin. Kandungan tersebut akan memperbaiki profil lipid dengan cara mengubah penyerapan hati, perakitan dan sekresi trigliserida, dan pengolahan lipoprotein plasma (Ray Sahelian, 2005). Selain itu, polifenol dapat meningkatkan kadar HDL dengan cara meningkatkan enzim Paraoxanase yang dapat meningkatkan aktivitas HDL (Utah University, 2003).

Buah ini membuat sistem pertahanan tubuh menjadi lebih solid. Kandungan vitamin C, niasin, kalsium, fosfor, magnesium, besi, natrium, kalium, dekstrosa, sukrosa, polifenol serta enzim bromelain yang tersimpan dalam buah nanas merupakan peluru tangguh yang bisa mengalahkan serbuan penyakit-penyakit serius, seperti tumor, aterosklerosis (penyempitan pembuluh darah), dan beri-beri (Sabella, 2010). Kandungan yang diduga dapat memperbaiki profil lipid antara lain vitamin C, niasin, dan Myricetin. Vitamin C, memperbaiki profil lipid dengan membentuk cairan empedu melalui eksresi kolesterol ekstra 
hepatik (Wibowo, 2003). Niasin memiliki efek antidislipidemia (FKUI, 2007). Pada dosis besar, Niasin dapat menurunkan kolesterol dan asam lemak bebas dalam darah. Niasin sudah dikenal luas untuk pengobatan dislipidemia. Niasin akan menghambat transport lemak ke hati sehingga akan mengurangi sintesis trigliserida (FKUI, 2007).

Nanas merupakan tanaman buah berupa semak yang memiliki nama ilmiah Ananas comosus. Memiliki nama daerah Sumatera: Ekahauku (Enggano), anes (Aceh), nas (Gayo), henas, kenas, honas, hanas (Batak), gona (Nias), asit, nasit (Mentawai), enas, kanas, dan nanas (Melayu). Dalam bahasa Inggris disebut Pineapple dan orang-orang Spanyol menyebut Pina. Di Indonesia pada mulanya hanya sebagai tanaman pekarangan, dan meluas dikebunkan di lahan kering di seluruh wilayah Nusantara. Tanaman ini kini dipelihara di daerah tropik dan sub tropik (Menegristek, 2010). Berdasarkan ciri, secara umum, buah nanas merupakan herbal tahunan atau dua tahunan, tingginya kira-kira $50-150 \mathrm{~cm}$. Nanas mempunyai tunas merayap pada bagian pangkalnya. Daunnya berkumpul dalam roset akar dan pada bagian pangkalnya melebar menjadi pelepah. Helaian daun berbentuk pedang, tebal, liat, panjang 80-120 cm, lebar 2-6 cm, ujung lancip menyerupai duri, tepi berduri tempel yang membengkok ke atas, sisi bawah bersisik putih, berwarna hijau atau hijau kemerahan. Bunga majemuk tersusun dalam bulir yang sangat rapat, letaknya terminal dan bertangkai panjang. Buahnya buah buni majemuk, bulat, panjang, berdaging, berwarna hijau, dan jika masak warnanya menjadi kuning. Buah nanas rasanya enak, asam sampai manis. Bijinya kecil, seringkali tidak jadi. Akarnya hitam keputih-putihan (Menegristek, 2007).

Buah yang kulitnya dipenuhi sisik emas ini membuat sistem pertahanan tubuh menjadi lebih solid. Kandungan vitamin C, niasin, kalsium, fosfor, magnesium, besi, natrium, kalium, dekstrosa, sukrosa, polifenol serta enzim bromelain yang tersimpan dalam buah nanas merupakan peluru tangguh yang bisa mengalahkan serbuan penyakitpenyakit serius, seperti tumor, aterosklerosis (penyempitan pembuluh darah), dan beri-beri (Sabella, 2010). Kandungan tersebut yang diduga dapat memperbaiki profil lipid an vitamin C, niasin, dan Myricetin.

Vitamin C dapat memperbaiki profil lipid dengan cara membentuk cairan empedu melalui eksresi kolesterol ekstra hepatik (Wibowo, 2003). Niasin memiliki efek antidislipidemia (FKUI, 2007). Pada dosis besar, Niasin dapat menurunkan kolesterol dan asam lemak bebas dalam darah. Niasin sudah dikenal luas untuk pengobatan dislipidemia. Niasin akan menghambat transport lemak ke hati sehingga akan mengurangi sintesis trigliserida (FKUI, 2007).

Polifenol adalah keluarga besar senyawa alam luas dalam makanan. Polifenol terdapat pada semua makanan nabati dan dan berkontribusi terhadap kesehatan. Polifenol dan senyawa terkait lain dapat ditemukan di setiap jenis tumbuhan. Karena kelimpahan polifenol di alam, maka tidak mengherankan bahwa polifenol dapat ditemukan dalam buah-buahan, sayuran, kopi, teh, coklat, dan kedelai. Polifenol memiliki subclass yang dibedakan melalui gugus kimianya antara lain, Flavonoid, Anthocyanin, Proanthocyanidins, dan 8 Resveratrol. Kontribusi polifenol sebagai antioksidan lebih besar daripada vitamin. Polifenol akan melindungi sel-sel dan tubuh terhadap kerusakan yang disebabkan oleh radikal bebas, atom reaktif yang dapat merusak sel-sel dalam tubuh (Ray Sahelian, 2005).

Flavonoid diduga merupakan senyawa polifenol yang terdapat dalam buah nanas (American Social Society, 1997). Flavonoid merupakan sekelompok senyawa fenolik yang telah teridentifikasi sebagai senyawa alami pada tumbuhan yang merupakan pigmen tumbuhan yang memproduksi warna kuning dan merah (Cut Fatima, 2008). Flavonoid dapat memperbaiki profil lipid dengan cara menghambat penyerapan lemak (Pal et al, 2003). Selain sebagai antidislipidemia, flavonoid juga terkenal sebagai antihistamin, anti kanker, dan cardioprotective (Van de Wiel, 2002).

Flavonoid terdiri dari Myricetin, Kaempferol, Luteolin, Apigenin dan Quercetin (Salisburry, 1995; Miean Hui 2001 ).

Penelitian di Universitas Madrid menyatakan bahwa, Myricetin dan Kaempferol adalah flavonoid yang diidentifikasi pada buah nanas (American Social Society, 1997; Miean Hui, 2001 ). Kaempferol dan Myricetin merupakan salah satu anggota flavonoid yang banyak ditemukan di dalam sayursayuran, buah-buahan, rempah-rempah, dan tanaman lainnya. Kaempferol merupakan senyawa yang memiliki efek antiproliferatif dan antiinflamasi (Farmasi UGM, 2011). Myricetin yang merupakan salah satu jenis flavonoid yang dapat mengubah penyerapan kolestererol, perakitan sekresi trigliserida dan pengolahan lipoprotein plasma (Ray Sahelian, 2005). Tim peneliti dari fakultas MIPA Universita Negeri Surakarta pada tahun 2003 menyatakan bahwa buah nanas mengandung Myricetin dengan kadar yang cukup tinggi dibanding dengan buah lainnya yaitu 0,4919 mg. Selain pada buah nanas, Myricetin juga dapat ditemukan pada buah anggur sebagai antioksidan (Sulistiono, 2010).

\section{Profil Lipid}

Dislipidemia adalah kelainan metabolisme lipid yang ditandai dengan peningkatan maupun penurunan fraksi lipid dalam plasma. Kelainan fraksi lipid yang paling utama adalah kenaikan kadar kolesterol total, kolesterol LDL, kenaikan kadar trigliserida dan penurunan kadar HDL (Bahri Anwar, 2004).

Hiperlipidemia adalah keadaan terdapatnya akumulasi berlebih salah satu atau lebih lipid utama di dalam plasma, sebagai manifestasi kelainan metabolisme atau transportasi lipid. Dalam klinis, hiperlipidemia dinyatakan sebagai hiperkolesterolemia, hipertrigliseridemia, atau kombinasi keduanya. Hiperlipidemia seringkali dikaitkan dengan risiko terjadinya aterosklerosis atau PJK, dan kadang-kadang juga dengan kelainan lain seperti xantomantosis dan pankreatitis (Suyono, 1996).

Hiperlipidemia dapat terjadi karena defek transportasi lipid atau karena produksi endogen berlebihan. Sedangkan hiperlipidemia sekunder disebabkan oleh suatu penyakit tertentu, misalnya diabetes melitus, gangguan tiroid, penyakit hepar, dan gangguan ginjal.

Sedangkan hiperlipidemia sekunder disebabkan oleh suatu penyakit tertentu, misalnya diabetes melitus, gangguan 
tiroid, penyakit hepar, dan gangguan ginjal. Hiperlipidemia merupakan suatu hal yang reversible (Suyono, 1996).

Secara klinis terutama dalam hubungannya dengan PJK dan pengobatannya, dislipidemia dapat dikategorikan ke dalam tiga bentuk, bergantung kepada kadar lipid yang meningkat, yaitu:

Hiperkolesterolemia (kolesterol meningkat)

Hipertrigliseridemia (trigliserida meningkat)

Hiperlipidemia campuran (kolesterol dan trigliserida meningkat) (Suyono, 1996)

Hubungan antara aterosklerotik dan metabolisme lemak telah menjadi perhatian ahli patologi dalam abad 19 dan semakin menjadi perhatian setelah Getler (1950) melaporkan bahwa kadar kolesterol pada pasien penyakit jantung koroner lebih tinggi dibandingkan orang normal. Gofman (1950) mendapatkan peningkatan LDL pada pasien penyakit koroner. Albrink dan Mann (1959) mendapatkan bahwa kadar trigliserida pada pasien penderita penyakit koroner juga meningkat (FKUI, 2007).

Kadar kolesterol serum yang tinggi akan meningkatkan risiko PJK karena sekitar $70 \%$ dari kolesterol ini akan ditranspor dalam bentuk LDL, sedangkan HDL akan menurunkan risiko PJK. Oksidasi LDL pada lapisan subendotel arteri akan menyebabkan berbagai macam reaksi inflamasi, yang akhirnya menarik monosit dan neutrofil ke area lesi. Sel-sel darah putih ini akan melekat pada lapisan endotel oleh molekul adhesif, dan melepaskan mediator inflamasi lain yang menarik makin banyak sel darah putih ke area tersebut dan selanjutnya merangsang oksidasi LDL. Pada akhirnya monosit bergerak masuk ke dinding arteri yang merupakan tempat pematangan menjadi makrofag dan mengubah LDL menjadi sel buih (Corwin, 2008). Hal tersebut akan memicu penimbunan plak di pembuluh darah. Akibat dari penimbunan plak tersebut maka akan terjadi penyempitan lumen yang kemudian akan menyebakan iskemia, misalnya PJK (Sibernagl, 2007).

\section{Kolesterol}

Kolesterol adalah lemak berwarna kekuningan berbentuk seperti lilin yang diproduksi oleh tubuh, terutama di dalam hati (Heslet, 1996). Kolesterol didalam tubuh mempunyai fungsi ganda, yaitu di satu sisi diperlukan dan di sisi lain dapat membahayakan bergantung berapa banyak terdapat di dalam tubuh dan di bagian mana (Sunita, 2009). Kolesterol merupakan komponen esensial membran struktural semua sel dan merupakan komponen utama sel otak dan saraf. Kolesterol terdapat dalam konsentrasi tinggi dalam jaringan kelenjar dan di dalam hati di mana kolesterol disintetis dan disimpan. Kolesterol merupakan bahan antara pembentukan sejumlah steroid penting, seperti asam empedu, asam folat, hormon-hormon adrenal korteks, estrogen, androgen, dan progesteron (Sunita,2009). Sebaliknya kolesterol dapat membahayakan tubuh. Kolesterol bila terdapat terlalu banyak di dalam darah dapat membentuk endapan pada dinding pembuluh darah sehingga menyebabkan penyempitan yang dinamakan aterosklerosis. Bila penyempitan terjadi pada pembuluh darah jantung dapat menyebabkan penyakit jantung koroner dan bila pada pembuluh darah otak dapat menyebabkan penyakit serebrovaskular (Sunita, 2009).
Kolesterol dan turunan esternya, dengan lemak berantai panjang adalah komponen penting dari lipoprotein plasma dan membran sel (Lehninger, 1990). Kolesterol diperlukan tubuh untuk membentuk hormon seks, vitamin D, dan garam empedu (Heslet, 1996).

Menurut Muchtadi, tahun 1993, kolesterol diangkut oleh darah dalam bentuk terikat dalam lipoprotein plasma. Lipoprotein plasma meliputi:

\section{Kilomikron}

Kilomikron adalah lipoprotein paling besar dan mempunyai densitas paling rendah. Kilomikron mengangkut lipida yang berasal dari makanan dari saluran cerna ke seluruh tubuh. Lipida yang diangkut termasuk trigliserida. Kilomikron tetesan besar lipida berupa trigliserida, kolesterol, dan fosfolipida dengan sedikit protein (terutama berupa apolipoprotein A dan B) yang membentuk selaput pada permukaannya.

Selaput di sekeliling kilomikron ini memungkinkan lipida di dalamnya mengambang secara bebbas di dalam aliran darah yang sebagian besar terdiri atas air (Sunita, 2009). Pada jenis lipoprotein ini kandungan lemaknya tinggi, densitas rendah komposisi trigliserida tinggi dan membawa sedikit protein (Krisnatuti dan Rina, 1999). Kilomikron membawa trigliserida dari makanan ke jaringan lemak dan otot rangka, juga membawa kolesterol ke hati. Trigliserida dari kilomikron akan terhidrolisis oleh LPL (FKUI, 2007).

\section{VLDL}

Di dalam hati, lipida dipersiapkan menjadi lipoprotein sehingga dapat diangkut melalui aliran darah. Lipoprotein yang dibentuk di dalam hati ini adalah VLDL (Sunita, 2009). VLDL merupakan senyawa yang berat jenisnya sangat rendah. Jenis lipoprotein ini memiliki kandungan lipid tinggi. Lipoprotein ini terdiri dari $60 \%$ trigliserida endogen dan $10-15 \%$ kolesterol. Trigliserida VLDL akan dihidrolisis oleh LPL yang akan menghasilkan asam lemak bebas untuk disimpan dalam jaringan adiposa dan bahan oksidasi di jantung dan otot skelet. Sebagian VLDL akan diubah menjadi LDL sehingga kadar LDL meningkat. Efek aterogenik VLDL belum begitu jelas tetapi hipertrigliseridemia merupakan tanda bahwa kadar HDL rendah dan sering dihubungkan dengan kegemukan, intoleransi glokosa dan hiperurisemia (FKUI, 2007)

\section{LDL}

LDL merupakan lipoporotein pengangkut kolesterol terbesar pada manusia (70 \% total). Partikel LDL mengandung trigliserida sebanyak $10 \%$ dan kolesterol sebanyak 50\% (FKUI, 2007). LDL merupakan senyawa lipoprotein yang berat jenisnya rendah. Lipoprotein ini membawa lemak dan mengandung kolesterol yang sangat tinggi, dibuat dari lemak endogenous di hati (Heslet, 1996). LDL yang terutama terdiri atas kolesterol bersirkulasi dalam tubuh dan dibawa ke sel-sel otot, lemak, dan sel-sel lain (Sunita, 2009). Jalur utama katabolisme LDL berlangsung lewat receptor mediated endocytosis di hati dan sel lain. Ester kolesterol dari inti LDL dihidrolisis menghasilkan kolesterol bebas, untuk sintesis sel membran dan hormon steroid.

Selain lewat proses endositosis sel juga mendapat kolesterol dari sintesis de novo lewat enzim HMG-CoA 
reduktase. Produksi enzim ini diatur lewat transkripsi genetik berdasarkan tinggi rendahnya kadar kolesterol dalam sel (FKUI, 2007). LDL merupakan kolesterol jahat karena memiliki sifat aterogenik (mudah melekat pada dinding sebelah dalam pembuluh darah dan mengurangi pembentukan reseptor LDL). Hal ini akan menyebabkan terjadinya kenaikan kadar kolesterol-LDL (Heslet, 1996).

\section{IDL}

IDL merupakan lipoprotein berdensitas antara. IDL ini kurang mengandung trigliserida (30\%), lebih banyak mengandung kolesterol $(20 \%)$ dan relatif lebih banyak mengandung apoprotein B dan E. IDL adalah zat perantara yang terjadi sewaktu VLDL dikatabolisme menjadi LDL, tidak terdapat dalam kadar yang besar kecuali bila terjadi hambatan konversi lebih lanjut. Bila terdapat dalam jumlah banyak, IDL akan terlihat sebagai kekeruhan pada plasma yang didinginkan meskipun ultra-sentrifugasi perlu dilakukan untuk memastikan adanya IDL (FKUI, 2007)

\section{HDL}

HDL merupakan senyawa lipoprotein yang berat jenisnya tinggi. Membawa lemak total rendah, tinggi protein, dan dibuat dari lemak endogenous di hati. Oleh karena kandungan kolesterol yang lebih rendah dari LDL dan fungsinya sebagai pembuangan kolesterol maka HDL ini sering disebut kolesterol baik. HDL ini digunakan untuk mengangkut kolesterol berlebihan dari seluruh jaringan tubuh untuk dibawa ke hati. Dengan demikian, HDL merupakan lipoprotein pembersih kelebihan kolesterol dalam jaringan (Wirahadikusumah, 1989).

HDL dapat di subklasifikasikan ke dalam HDL1, HDL2, HDL3 dan berdasarkan kandungan Apo A-I dan Apo A-II nya. Metabolisme HDL kompleks dan terdapat petunjuk bahwa Apo A-I plasma yang merupakan apoprotein utama HDL merupakan inverse predictor untuk resiko penyakit jantung koroner yang lebih baik daripada HDL. Kadar HDL akan menurun pada kegemukan, perokok, pasien diabetes yang tidak terkontrol dan pada pemakai kombinasi estrogenprogestin (FKUI, 2007).

\section{KERANGKA KONSEPTUAL}

\section{Kerangka Konseptual Penelitian}
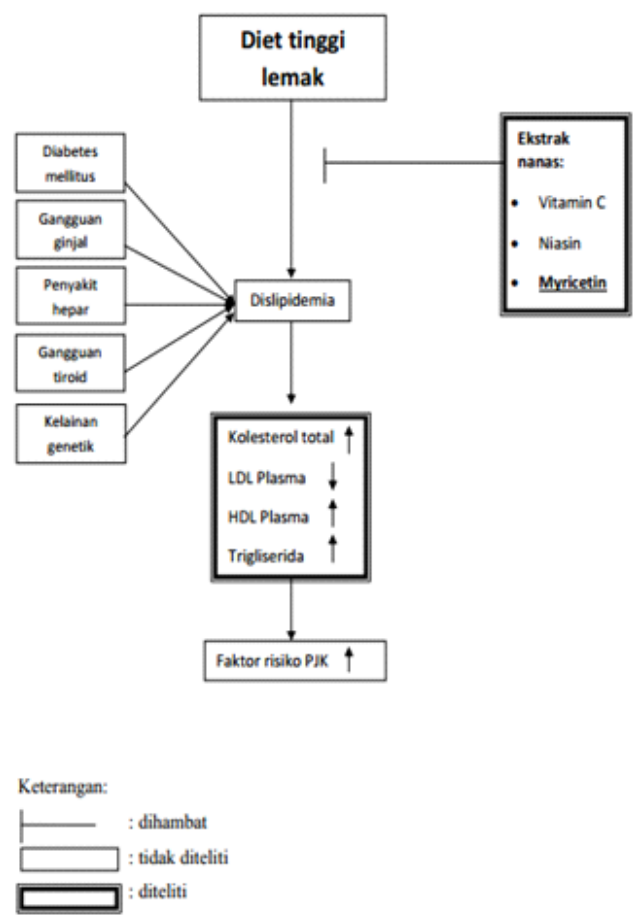

Dislipidemia dapat berupa peningkatan kadar kolesterol total atau hiperkolesterolemia, penurunan kadar HDL, peningkatan LDL atau peningkatan kadar trigliserida dalam darah (hipertrigliserida) (Anwar, 2004). Dislipidemia dapat disebabkan karena Diabetes Mellitus, gangguan tiroid, penyakit ginjal, penyakit hepar dan diet tinggi lemak (Suyono,1996). Dengan adanya dislipidemia maka risiko penyakit PJK akan meningkat (FKUI; Universitas Ohio, 1997)

Dengan pemberian ekstrak buah nanas yang mengandung Vitamin C, Niasin, dan Myricetin diduga dapat menghambat sintesis kolesterol sehingga mencegah keadaan dislipidemia dan menurunkan resiko PJK.

\section{HIPOTESIS PENELITIAN}

Terdapat pengaruh ekstrak buah nanas (Ananas Comosus L. Merr) terhadap perbaikan profil lipid pada tikus putih jantan (Rattus Norvegicus) dislipidemia.

\section{METODE PENELITIAN}

\section{Alat dan Bahan}

Alat-alat yang digunakan adalah: a)Timbangan untuk menimbang berat badan tikus. b) Timbangan elektrik dengan ketelitian 0,01 gram untuk menimbang ekstrak nanas. c) Kandang tikus. d) Mikrohematokrit. e) Rak dan tabung reaksi. f) Ependrof g) Mikropipet h) Sentrifuge i) Spektrofotometer j) Gelas ukur k) Jarum sonde l) 2 Cawan petri.

Bahan yang digunakan dalam penelitian ini adalah: a) Hewan percobaan b) Pakan dislipidemia (kolesterol 0,1\%, asam kolat $0,05 \mathrm{~g}$, lemak sapi $20 \mathrm{ml}$, minyak kelapa $20 \mathrm{ml}$, terigu 5gr, kuning telur 10 gr, dan pakan BR-1 30 gr per ekor perhari (Fadlina C.S dkk, 2007)). c) Pakan standar d) Air 
minum e) Ekstrak nanas, diberikan sesuai dengan dosis yang dibutuhkan f) Aquades

Berdasarkan dosis aman buah nanas yang dikonsumsi oleh manusia yaitu 2 kali sehari 2 x 100 gram setara dengan 200 gram perhari (Sabella, 2010). Pemberian dosis ekstrak nanas untuk tikus dengan menggunakan tabel perbandingan luas permukaan tubuh hewan percobaan untuk konversi dosis manusia dengan berat badan $70 \mathrm{~kg}$ ke berat badan tikus 200 gram adalah 0,018 (Donatus, 1994). Dengan demikian perhitungan konversi dosis jus nanas adalah sebagai berikut: 200 x 0,018 = 3,6 gr/200gBB, digenapkan menjadi $3,5 \mathrm{gr} / 200 \mathrm{gBB}$. Selanjutnya dosis tersebut digunakan sebagai nilai tengah perlakuan, sehingga didapatkan dosis untuk perlakuan lainnya adalah 3 gr/ ekor/hari dan $4 \mathrm{gr} /$ ekor/hari.

\section{Pembuatan Ekstrak Nanas}

Populasi dalam penelitian ini adalah tikus jantan, dan sampel yang digunakan adalah tikus putih jantan dewasa yang diambil secara acak dari populasi tikus putih jantan sebagai hewan coba.

Mula-mula ambil daging buah nanas sebanyak $1 \mathrm{~kg}$ yang telah dibersihkan dari getah dan kotorannya, iris kecilkecil kemudian blender. Mengambil sari buah nanas lalu tambahkan sedikit pelarut etanol 95\% hingga menjadi bubur.

Menambahkan pelarut etanol $3000 \mathrm{ml}$ atau tiga kali dari massa bahan pada bubur tersebut, bubur diaduk hingga homogen lalu ditutup dengan alumunium foil pada suhu $4^{\circ} \mathrm{C}$ selama 24 jam. Melakukan penyaringan untuk memisahkan filtrate dari ampasnya.

Melakukan proses evaporasi dengan baik pada suhu $40^{\circ} \mathrm{C}$ dengan kecepatan 10-20rpm dan tekanan hisap $2 \mathrm{~atm}$. Proses evaporasi berlangsung sampai didapatkan cairan ekstrak pekat yang telah terpisah dengan pelarut etanol yang diuapkan, dimana proses dikatakan dapat dihentikan jika tidak terjadi tetesan pelarut etanol pada labu penampung.

\section{Penentuan Dosis Ekstrak Nanas}

Pemberian dosis ekstrak nanas untuk tikus dengan menggunakan tabel perbandingan luas permukaan tubuh hewan percobaan untuk konversi dosis manusia dengan berat badan $70 \mathrm{~kg}$ ke berat badan tikus 200 gram adalah 0,018 (Donatus, 1994). Dengan demikian perhitungan konversi dosis jus nanas adalah sebagai berikut: $200 \times 0,018$ $=3,6 \mathrm{gr} / 200 \mathrm{gBB}$, digenapkan menjadi $3,5 \mathrm{gr} / 200 \mathrm{gBB}$. Selanjutnya dosis tersebut digunakan sebagai nilai tengah perlakuan, sehingga didapatkan dosis untuk perlakuan lainnya adalah $3 \mathrm{gr} / \mathrm{ekor} /$ hari dan $4 \mathrm{gr} / \mathrm{ekor} /$ hari.

\section{Perlakuan pada Tikus}

a. Mengelompokkan tikus putih percobaan yang berjumlah 25 ekor secara random menjadi 5 kelornpok, yaitu dua kelompok kontrol dan 3 kelompok perlakuan.

b. Tiap tikus dinaikkan kadar kolesterol darahnya dengan cara memberikan pakan diet dislipidemia.

c. Tikus dislipidemia diperlakukan sebagai berikut : Kelompok I: Sebagai kontrol negatif diberi pakan standar tanpa pemberian pakan diet tinggi lemak dan ekstrak nanas. Kelompok II: Sebagai kontrol positif diberi pakan diet dislipidemia tanpa pemberian ekstrak nanas. Kelompok III: Pakan dislipidemia + ekstrak nanas dengan dosis $3 \mathrm{gr} / 200 \mathrm{grBB} /$ hari diberikan 2 kali sehari. Kelompok IV: Pakan dislipidemia + ekstrak nanas dengan dosis 3,5 gr/200grBB/hari diberikan 2 kali sehari. 32 Kelompok V: Pakan dislipidemia + ekstrak nanas dengan dosis $4 \mathrm{gr} / 200 \mathrm{grBB} /$ hari diberikan 2 kali sehari.

d. Pemberian ekstrak nanas dilakukan per oral selama 14 hari (2 minggu).

e. Pada hari ke-15 tikus darahnya diambil dengan rnikrohematokrit melalui ventrikel kiri sebanyak \pm 3 $\mathrm{ml}$ untuk diukur kadar profil lipidnya.

\section{Pemeriksaan Lipoprotein}

Plasma Darah yang telah diambil dari ventrikel kiri sebanyak $\pm 3 \mathrm{ml}$, dilakukan sentrifuge dengan kecepatan 6000 rpm selama 10 menit untuk mengambil supernatannya. Dari supernatan tersebut, kemudian dilakukan pemeriksaan lipoprotein plasma (kolesterol HDL dan kolesterol LDL).

\section{Pengamatan Hasil}

Hasil perhitungan rasio LDL/HDL plasma diolah dengan mencari rerata dan standar deviasi pada setiap kelompok.

\section{Perlakuan Pada Tikus}

a. Mengelompokkan tikus putih percobaan yang berjumlah 25 ekor secara random menjadi 5 kelornpok, yaitu dua kelompok kontrol dan 3 kelompok perlakuan.

b. Tiap tikus dinaikkan kadar kolesterol darahnya dengan cara memberikan pakan diet dyslipidemia

c. Tikus dislipidemia diperlakukan sebagai berikut :

d. Kelompok I: Sebagai kontrol negatif diberi pakan standar tanpa pemberian pakan diet tinggi lemak dan ekstrak nanas.

e. Kelompok II: Sebagai kontrol positif diberi pakan diet dislipidemia tanpa pemberian ekstrak nanas.

f. Kelompok III: Pakan dislipidemia + ekstrak nanas dengan dosis 3 gr/200grBB/hari diberikan 2 kali sehari. Kelompok

g. IV: Pakan dislipidemia + ekstrak nanas dengan dosis $3,5 \mathrm{gr} / 200 \mathrm{grBB} /$ hari diberikan 2 kali sehari. 32 Kelompok

h. V: Pakan dislipidemia + ekstrak nanas dengan dosis 4 gr/200grBB/hari diberikan 2 kali sehari.

d. Pemberian ekstrak nanas dilakukan per oral selama 14 hari (2 minggu).

e. Pada hari ke-15 tikus darahnya diambil dengan rnikrohematokrit melalui ventrikel kiri sebanyak \pm 3 $\mathrm{ml}$ untuk diukur kadar profil lipidnya.

\section{Pemeriksaan Lipoprotein Plasma}

1. Penentuan kadar kolesterol darah

2. Penentuan Kadar HDL Metode CHOP-PAP

3. Penentuan Kadar Trigliserida Dalam Darah Metode GPO-PAP

4. Perhitungan Konsentrasi LDL

\section{Pengamatan Hasil}

Hasilperhitungan rasio LDL/HDL plasma diolah dengan mencari rerata dan standar deviasi pada setiap kelompok. 


\section{HASIL DAN ANALISIS DATA}

Data hasil pengamatan dikumpulkan dan disajikan dalam bentuk tabel, grafik, dan analisis statistik uji One-Way ANOVA (Analysis of Variance).

Penelitian ini merupakan penelitian true experiment dengan Post Test Control Group Design untuk membuktikan pengaruh pemberian ekstrak nanas (Ananas Comosus L. merr) terhadap perbaikan profil lipid pada tikus putih jantan (Rattus norvegicus strain wistar) dislipidemia. Profil lipid yang diukur yaitu HDL, LDL, TG, Kolesterol Total, dan rasio LDL/HDL. Pengukuran dilakukan setelah pemberian nanas (Ananas Comosus L. merr) yang diberikan pada kelompok III, $\mathrm{IV}$, dan $\mathrm{V}$ dengan dosis $3 \mathrm{ml} / 200 \mathrm{grBB} /$ hari, 3,5 ml/ $200 \mathrm{grBB} /$ hari, dan $4 \mathrm{ml} / 200 \mathrm{grBB} /$ hari selama 14 hari.

\section{Pengaruh Pemberian Ekstak Nanas Terhadap Kolesterol LDL Tikus Putih Jantan Dislipidemia}

Hasil pengukuran kolesterol LDL serum tikus putih dislipidemia dapat dilihat pada tabel berikut.

\begin{tabular}{|c|c|}
\hline Perlakuan & Rerata hasil (mg/dl) \pm SD \\
\hline Kelompok 1 (kontrol nceatif)/normal & $15,06 \pm 4,57$ \\
\hline Kelompok 2 (kontrol positif)/diet dislipidemia & $224,15 \pm 5,03$ \\
\hline $\begin{array}{l}\text { Kelompok } 3 \text { (diet dislipidemia + ckstrak nanas } 3 \\
\text { gr/ckor/hari) }\end{array}$ & $144,74 \pm 7,56$ \\
\hline $\begin{array}{l}\text { Kelompok } 4 \text { (diet dislipidemia + ckstrak nanas } 3,5 \\
\text { gr/ckor/hari) }\end{array}$ & $91,18 \pm 2,33$ \\
\hline $\begin{array}{l}\text { Kelompok } 5 \text { (diet dislipidemia + ekstrak nanas } 4 \\
\text { grrckor/hari) }\end{array}$ & $36,90 \pm 5,32$ \\
\hline
\end{tabular}

Data yang diperoleh kemudian dilakukan uji Normalitas. Hasil uji Normalitas menunjukan bahwa nilai sig $=0,070$ lebih besar dari pada $\mathrm{p}(0,05)$ yang berarti distribusi bersifat normal.

Selain itu dilakukan juga uji Homogenitas yang menunjukkan bahwa nilai sig $=0,317$ lebih besar dari pada p $(0,05)$ yang berarti varian data bersifat Homogen. Data yang memenuhi asumsi normal dan homogen kemudian dilanjutkan dengan uji Anova. Hasil uji Anova menunjukkan bahwa nilai sig $=0,000$ lebih kecil dari pada $\mathrm{p}(0,05)$ yang berarti terdapat pengaruh yang bermakna terhadap kadar LDL tikus putih. Hasil lebih lanjut menunjukkan bahwa pada pemberian dosis ekstrak nanas $3 \mathrm{gr} /$ ekor (kelompok 3) sudah menunjukkan adanya penurunan kadar kolesterol LDL dan berbeda bermakna dengan pemberian dosis 3,5 gr/ekor (kelompok 4) dan dosis 4 gr/ekor (kelompok 5). Serta menunjukkan bahwa kelompok 5 mengalami penurunan yang paling besar dan sudah hampir menyamai kadar kolesterol LDL kelompok tikus putih normal. Uji Korelasi menunjukkan bahwa nilai sig (2-tailed) $0,000<\mathrm{p}$ $(0,05)$ dengan koefisien korelasi $(r)=-0,977$ yang berarti terdapat hubungan yang berbanding terbalik sangat bermakna yang berarti kenaikan dosis nanas menyebabkan penurunan kadar kolesterol LDL tikus putih dislipidemia pada akhir penelitian. Hasil uji Regresi menunjukkan bahwa persamaan yang menyatakan hubungan antara dosis nanas dengan kadar LDL serum adalah $\mathrm{Y}=233,606-41,663(\mathrm{X})$, dimana $\mathrm{Y}$ adalah kolesterol LDL dan $\mathrm{X}$ adalah dosis nanas ( $\mathrm{ml} /$ ekor).

Hasil uji Regresi menunjukkan bahwa persamaan tersebut dapat diterima dan dapat digunakan dengan nilai koefisien determinasi $(\mathrm{R} 2)=0,875$. Grafik persamaan regresi yang menggambarkan hubungan antara dosis nanas dan penurunan kolesterol LDL dapat dilihat sebagai berikut.

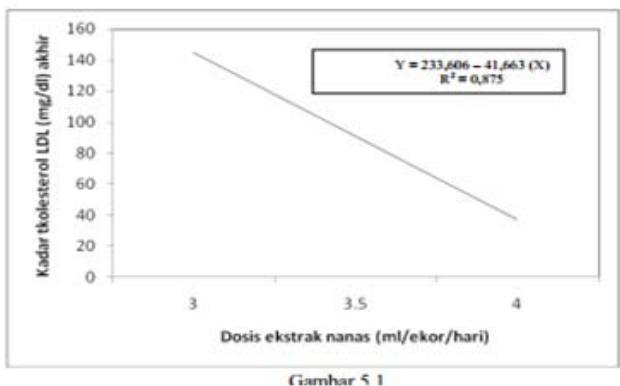

\section{Pengaruh Pemberian Nanas terhadap Kolesterol HDL Tikus Putih Jantan Dislipidemia}

Hasil pengukuran HDL serum darah tikus putih dapat dilihat dari tabel berikut.

Tabel 5.2 Data Pengukuran HDL Tikus Putih
\begin{tabular}{|l|r|}
\hline Perlakuan & Rerata hasil (mg/dl) \pm SD \\
\hline Kelompok I (kontrol negatif)/normal & $85,58 \pm 3,41$ \\
\hline Kelompok 2 (kontrol positif)/diet dislipidemia & $33,54 \pm 2,33$ \\
\hline $\begin{array}{l}\text { Kelompok 3 (diet dislipidemia + ekstrak nanas 3 } \\
\text { gr/ckor/hari) }\end{array}$ & $46,81 \pm 4,12$ \\
\hline $\begin{array}{l}\text { Kelompok 4 (diet dislipidemia + ckstrak nanas 3,5 } \\
\text { gr/ckor/hari) }\end{array}$ & $56,73 \pm 4,12$ \\
\hline $\begin{array}{l}\text { Kelompok 5 (diet dislipidemia + ekstrak nanas 4 } \\
\text { gr/ckor/hari) }\end{array}$ & $74,34 \pm 2,08$ \\
\hline
\end{tabular}

Data yang diperoleh kemudian dilakukan uji Normalitas. Hasil uji Normalitas menunjukkan bahwa sig $=0,200$ lebih besar dari pada $\mathrm{p}(0,05)$ yang berarti distribusi data bersifat normal.

Selain itu, dilakukan juga uji Homogenitas. Hasil uji Homogenitas menunjukkan bahwa sig $=0,800$ lebih besar daripada $\mathrm{p}(0,05)$ yang berarti varian data bersifat homogen.

Data yang memenuhi asumsi normal dan homogen dilanjutkan dengan uji Anova. Hasil uji Anova menunjukkan bahwa sig $=0,000$ lebih kecil dari pada $\mathrm{p}(0,05)$ yang berarti terdapat pengaruh yang bermakna terhadap kadar kolesterol HDL tikus putih jantan dislipidemia.

Hasil lebih lanjut menunjukkan bahwa pada pemberian dosis nanas $3 \mathrm{gr} /$ ekor (kelompok 3) sudah menunjukkan adanya peningkatan kadar kolesterol HDL dan berbeda bermakna dengan pemberian dosis 3,5 gr/ekor (kelompok 4) dan dosis 4 gr/ekor (kelompok 5). Serta menunjukkan bahwa kelompok 5 mengalami peningkatan yang paling besar dan sudah hampir menyamai kadar kolesterool HDL kelompok tikus putih normal.

Uji Korelasi menunjukkan bahwa nilai sig (2-tailed) $0,000<\mathrm{p}(0,05)$ dengan koefisien korelasi $(\mathrm{r})=0,861$ yang berarti terdapat hubungan yang berbanding lurus yang berarti kenaikan dosis nanas menyebabkan peningkatan kadar kolesterol HDL tikus putih jantan dislipidemia pada akhir penelitian.

Hasil uji Regresi menunjukkan bahwa persamaan yang menyatakan hubungan antara dosis ekstrak nanas dengan kadar HDL serum adalah $\mathrm{Y}=30,808+8,399(\mathrm{X})$, dimana $\mathrm{Y}$ adalah kolesterol HDL dan $\mathrm{X}$ adalah dosis nanas ( $\mathrm{ml} /$ ekor). Hasil uji Regresi menunjukkan bahwa persamaan tersebut dapat diterima dan dapat digunakan dengan nilai koefisien determinasi $(\mathrm{R} 2)=0,742$. 
Pengaruh Pemberian Nanas terhadap Trigliserida Tikus Putih Jantan Dislipidemia

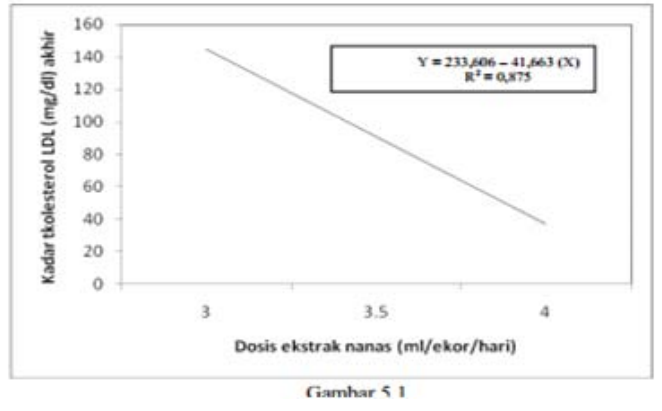

Hasil lebih lanjut menunjukkan bahwa pada pemberian ekstrak nanas dengan dosis 3 gr/ekor (kelompok 3) sudah menunjukkan adanya penurunan kadar Trigliserida dan berbeda bermakna dengan pemberian dosis 3,5 gr/ekor (kelompok 4) dan dosis 4 gr/ekor (kelompok 5). Serta menunjukkan bahwa kelompok 5 mengalami penurunan yang paling besar dan semakin mendekati kadar trigliserida kelompok tikus putih normal.

Uji Korelasi menunjukkan bahwa nilai sig (2-tailed) $0,000<\mathrm{p}(0,05)$ dengan koefisien korelasi $(\mathrm{r})=-0,845$ yang berarti terdapat hubungan yang berbanding terbalik yang berarti kenaikan dosis ekstrak nanas menyebabkan penurunan kadar trigliserida tikus putih pada akhir penelitian.

Hasil uji Regresi menunjukkan bahwa persamaan yang menyatakan hubungan antara dosis ekstrak nanas dengan kadar Trigliserida adalah Y $=196,368-13,018(\mathrm{X})$, dimana $\mathrm{Y}$ adalah kadar trigliserida dan $\mathrm{X}$ adalah dosis nanas (gr/ekor). Hasil uji Regresi menunjukkan bahwa persamaan tersebut pat diterima dan dapat digunakan dengan nilai koefisien determinasi $(\mathrm{R} 2)=0,714$.

\section{Pengaruh Pemberian Nanas terhadap Trigliserida Tikus Putih Jantan Dislipidemia}

Pengaruh Pemberian Nanas terhadap Trigliserida Tikus Putih Jantan Dislipidemia

\begin{tabular}{|l|r|}
\hline Perlakuan & Rerata hasil (mg/dl) \pm SD \\
\hline Kelompok I (kontrol negatif)/normal & $65,84 \pm 3,67$ \\
\hline Kelompok 2 (kontrol positif)/dict dislipidemia & $191,63 \pm 5,08$ \\
\hline $\begin{array}{l}\text { Kelompok 3 (diet dislipidemia + ckstrak nanas 3 } \\
\text { gr/ckor/hari) }\end{array}$ & $174,99 \pm 5,66$ \\
\hline $\begin{array}{l}\text { Kelompok 4 (diet dislipidemia + ckstrak nanas 3,5 } \\
\text { gr/ckor/hari) }\end{array}$ & $153,39 \pm 4,16$ \\
\hline $\begin{array}{l}\text { Kelompok 5 (diet dislipidemia + ckstrak nanas 4 } \\
\text { gr/ckor/hari) }\end{array}$ & $128,79 \pm 4,36$ \\
\hline
\end{tabular}

Data yang diperoleh kemudian dilakukan uji Normalitas. Hasil uji Normalitas menunjukkan bahwa sig $=0,115$ lebih besar dari pada $\mathrm{p}(0,05)$ yang berarti distribusi data bersifat normal.

Selain itu, dilakukan juga uji Homogenitas. Hasil uji Homogenitas menunjukkan bahwa sig $=0,938$ lebih besar daripada p $(0,05)$ yang berarti varian data bersifat homogen.

Data yang memenuhi asumsi normal dan homogen dilanjutkan dengan uji Anova. Hasil uji Anova menunjukkan bahwa sig $=0,000$ lebih kecil dari pada $\mathrm{p}(0,05)$ yang berarti terdapat pengaruh yang be rmakna terhadap kadar Trigliserida tikus putih jantan dislipidemia.
Hasil lebih lanjut menunjukkan bahwa pada pemberian ekstrak nanas dengan dosis 3 gr/ekor (kelompok 3) sudah menunjukkan adanya penurunan kadar Trigliserida dan berbeda bermakna dengan pemberian dosis 3,5 gr/ekor (kelompok 4) dan dosis 4 gr/ekor (kelompok 5). Serta menunjukkan bahwa kelompok 5 mengalami penurunan yang paling besar dan semakin mendekati kadar trigliserida kelompok tikus putih normal.

Uji Korelasi menunjukkan bahwa nilai sig (2-tailed) $0,000<\mathrm{p}(0,05)$ dengan koefisien korelasi $(\mathrm{r})=-0,845$ yang berarti terdapat hubungan yang berbanding terbalik yang berarti kenaikan dosis ekstrak nanas menyebabkan penurunan kadar trigliserida tikus putih pada akhir penelitian.

Hasil uji Regresi menunjukkan bahwa persamaan yang menyatakan hubungan antara dosis ekstrak nanas dengan kadar Trigliserida adalah Y $=196,368-13,018$ (X), dimana Y adalah kadar trigliserida dan $\mathrm{X}$ adalah dosis nanas (gr/ekor). Hasil uji Regresi menunjukkan bahwa persamaan tersebut dapat diterima dan dapat digunakan dengan nilai koefisien determinasi $(\mathrm{R} 2)=0,714$.

\section{Pengaruh Pemberian Ekstrak Buah Nanas Terhadap Kadar Kolesterol Total Tikus Putih Jantan Dislipidemia}

Hasil lebih lanjut menunjukkan bahwa pada pemberian ekstrak nanas dengan dosis 3 gr/ekor (kelompok 3) sudah menunjukkan adanya perbaikan kadar kolsterol total dan berbeda bermakna dengan pemberian dosis 3,5 gr/ekor (kelompok 4) dan dosis 4 gr/ekor (kelompok 5). Serta menunjukkan bahwa kelompok 5 mengalami penurunan yang paling besar dan sudah mendekati kadar kolesterol kelompok tikus putih normal.

Uji Korelasi menunjukkan bahwa nilai sig (2-tailed) $0,000<\mathrm{p}(0,05)$ dengan koefisien korelasi $(\mathrm{r})=-0,941$ yang berarti terdapat hubungan yang berbanding terbalik yang berarti kenaikan dosis ekstrak nanas menyebabkan penurunan kadar kolesterol total tikus putih jantan dislipidemia pada akhir penelitian.

Hasil uji Regresi menunjukkan bahwa persamaan yang menyatakan hubungan antara dosis ekstrak nanas dengan kadar kolesterol total serum adalah $\mathrm{Y}=303,687-35,867(\mathrm{X})$, dimana $\mathrm{Y}$ adalah kadar kolesterol total dan $\mathrm{X}$ adalah dosis nanas (gr/ekor). Hasil uji Regresi menunjukkan bahwa persamaan tersebut dapat diterima dan dapat digunakan dengan nilai koefisien determinasi $(\mathrm{R} 2)=0,885$. Grafik persamaan regresi yang menggambarkan hubungan antara dosis nanas dan penurunan kolesterol total.

\section{Kadar Rasio LDL/HDL Akhir}

Hasil lebih lanjut menunjukkan bahwa pada pemberian ekstrak nanas $3 \mathrm{gr} /$ ekor (kelompok 3) sudah menunjukkan adanya perbaikan kadar rasio LDL/HDL dan berbeda bermakna dengan pemberian dosis 3,5 gr/ekor (kelompok 4) dan dosis 4 gr/ekor (kelompok 5). Serta menunjukkan bahwa kelompok 5 mengalami penurunan yang paling besar dan sudah mendekati kadar rasio LDL/HDL kelompok tikus putih normal.

Uji Korelasi menunjukkan bahwa nilai sig (2-tailed) $0,000<\mathrm{p}(0,05)$ dengan koefisien korelasi $(\mathrm{r})=-0,975$ yang berarti terdapat hubungan yang berbanding terbalik yang 
berarti kenaikan dosis nanas menyebabkan penurunan kadar rasio LDL/HDL tikus putih pada akhir penelitian.

Hasil uji Regresi menunjukkan bahwa persamaan yang menyatakan hubungan antara dosis nanas dengan kadar kolesterol total serum adalah $\mathrm{Y}=6,878-1,483(\mathrm{X})$, dimana $\mathrm{Y}$ adalah kadar rasio LDL/HDL dan $\mathrm{X}$ adalah dosis nanas (gr/ekor). Hasil uji regresi menunjukkan bahwa persamaan tersebut dapat diterima dan dapat digunakan dengan nilai koefisien determinasi (R2) $=0,950$.

\section{PEMBAHASAN}

Penelitian ini dilakukan selama 4 minggu. Tikus diberi diet dislipidemia selama 2 minggu kemudian selama 2 minggu diberi ekstrak nanas untuk mengetahui pengaruh ekstrak nanas dalam memperbaiki komponen lipid pada tikus putih dislipidemia. Penelitian ini menunjukkan bahwa pemberian ekstrak nanas memberikan pengaruh yang bermakna terhadap kadar kolesterol LDL (sig $=0,000<\mathrm{p}$ $(0,05))$, trigliserida $(\mathrm{sig}=0,000<\mathrm{p}(0,05))$, kolesterol total $(\operatorname{sig}=0,000<\mathrm{p}(0,05))$, dan HDL $(\operatorname{sig}=0,000<\mathrm{p}(0,05))$ tikus putih dislipidemia.

Pada dosis terkecil yaitu $3 \mathrm{ml} /$ ekor/hari sudah mampu menurunkan kadar kolesterol LDL, trigliserida, kolesterol total, dan meningkatkan kadar kolesterol HDL. Terdapat hubungan antara kenaikan dosis ekstrak nanas dengan perbaikan kadar kolesterol LDL $(\mathrm{R} 2=0,875)$, trigliserida $(\mathrm{R} 2=0,714)$, kolesterol total $(\mathrm{R} 2=0,885)$, dan HDL (R2 $=0,742)$ tikus putih jantan dislipidemia.

Penelitian ini menggunakan tikus putih jantan yang kemudian diberi diet dislipidemia (kolesterol 0,1\%, asam kolat $0,05 \mathrm{~g}$, lemak sapi $20 \mathrm{ml}$, minyak kelapa $20 \mathrm{ml}$, terigu 5gr, kuning telur $10 \mathrm{gr}$, dan pakan BR-1 $30 \mathrm{gr}$ per ekor perhari (Fadlina C.S dkk, 2007) terbukti dapat meningkatkan kadar kolesterol LDL, trigliserida, kolesterol total, dan menurunkan kadar kolesterol HDL. Trigliserida dan kolesterol yang didapat dari diet hiperlipidemia (kolesterol $0,1 \%$, asam kolat $0,05 \mathrm{gr}$, lemak sapi $20 \mathrm{ml}$, minyak kelapa $20 \mathrm{ml}$, dan kuning telur $10 \mathrm{gr}$ ) diserap di mukosa usus halus karena pada dasarnya kolesterol merupakan produk metabolisme yang berasal dari hewan, seperti kuning telur, daging, hati, otak, dan lemak (Mayes, 2003).

Trigliserida akan diserap sebagai asam lemak bebas sedang kolesterol sebagai kolesterol. Dalam usus halus, asam lemak bebas akan diubah menjadi trigliserida, sedang kolesterol akan mengalami esterifikasi menjadi kolesterol ester dan keduanya bersama dengan fosfolipid dan apolipoprotein akan membentuk kilomikron. Bila sebagian besar trigliserida telah dipisahkan dari kilomikron, sisanya yang sebagian besar terdiri atas kolesterol dan protein dibawa ke hati dan mengalami metabolisme. Hati mempersiapkan lipida menjadi lipoprotein sehingga dapat diangkut melalui aliran darah yaitu VLDL.

Lipoprotein lipase akan memecah trigliserida yang ada pada VLDL menjadi LDL. LDL kemudian akan dibawa ke hati dan jaringan lainnya yang mempunyai reseptor LDL. HDL dilepaskan sebagai partikel kecil yang miskin kolesterol dan mengandung apolipoprotein (apo) A, C, dan E; dan disebut sebagai HDL nascent. HDL nascent berasal dari usus halus dan hati, mempunyai bentuk gepeng dan mengandung apolipoprotein A1. HDL nascent akan mendekati makrofag untuk mengambil kolesterol yang tersimpan didalam makrofag, HDL nascent berubah menjadi HDL dewasa yang berbentuk bulat. Perbaikan profil lipid dapat dilakukan dengan beberapa mekanisme antara lain dengan menghambat absorbsi kolesterol di usus halus, menghambat sintesis kolesterol dalam hati, menghambat transport asam lemak, dan meningkatkan eksresi kolesterol (FKUI, 2008). Kandungan ekstrak nanas yang diduga dapat 52 memperbaiki profil lipid antara lain vitamin C, niasin, dan myricetin.

Vitamin C dapat memperbaiki profil lipid dengan cara membentuk cairan empedu melalui eksresi kolesterol ekstra hepatik (Wibowo, 2003). Niasin memiliki efek antidislipidemia (FKUI, 2007) pada dosis besar, Niasin dapat menurunkan kolesterol dan asam lemak bebas dalam darah (FKUI, 2007). Niasin akan menghambat transport lemak ke hati sehingga akan mengurangi sintesis trigliserida (FKUI, 2007). Namun pada buah nanas belum dapat diketahui kandungan dan mekanisme pasti yang dapat memperbaiki profil lipid. Oleh karena itu perlu dilakukan penelitian lebih lanjut mengenai mekanisme pasti dan kandungan buah nanas dalam memperbaiki profil lipid.

\section{Kesimpulan}

Ekstrak buah nanas dapat menurunkan kadar LDL, Trigliserida, dan Kolesterol Total tikus putih jantan dyslipidemia, dapat meningkatkan kadar HDL tikus putih jantan dyslipidemia, dan penggunaan dosis ekstrak nanas efektif yang dalam memperbaiki profil lipid hingga mendekati normal adalah dosis 4 gr/ekor/hari.

\section{DAFTAR PUSTAKA}

FKUI, 2008, Farmakologi dan Terapi, Edisi 5, Departemen Farmakologi dan Terapeutik Fakultas Kedokteran Universitas Indonesia, Balai penerbit FKUI, Jakarta.

Mayes, P. 2003. Metabolisme Lemak, Biokimia Harper. EGC. Jakarta. Hal: 254- 286.

Sabella R, 2010, Libas Kolesterol dengan Terapi Herbal, Buah dan Sayuran, Galmas Publisher, Klaten.

Sahelian R, 2007, Myricetin Sebagai Obat Herbal, American Society Journal of Nutrition, America, No. 137, 240541.

Suyono S, 1996, Hiperlipidemia, Ilmu Penyakit Dalam, FKUI, Gaya Baru, Jakarta.

Van de Wiel, 2002, Flavonoid dan Penyakit Jantung, Liku Medisch Centrum, AFD. Interne Geneeskunde, Amersfoort.

Alhanin J, 2001, Kadar Kolesterol Serum Darah Mencit (Mus musculus) Swiss Webstar Setelah Pemberian Filtrat Bawang Merah (Alium cepa varascolinum). Skripsi. Semarang: Unnes Press.

Anwar. TB, 2004, Dislipidemia Sebagai Faktor Resiko PJK, FK USU, Sumatera Utara

Corwin JE, 2009, Buku Saku Patofisiologi, EGC, Jakarta. Heslet L, 1997, Kolesterol, Terjemahan Anton Adiwijoto, PT. Kesaint Blanc Indah, Jakarta.

Katzung BG, 1998, Farmakologi Dasar dan Klinik, alih bahasa : Staf Dosen Farmakologi Fakultas Kedokteran UNSRI, EGC, Jakarta. 